\title{
Kualitas Pernikahan pada Keluarga yang Terdampak Ekonomi selama Pandemi COVID-19
}

\section{Marital Quality of Economically Affected Families during the COVID-19 Pandemic}

\author{
Kholifah Umi Sholihah, Laksmi Rahmadian \\ Fakultas Psikologi Universitas Diponegoro, Semarang, Indonesia
}

\begin{abstract}
The quality of marriage is an important issue for every family. The marital quality depends on how each partner can manage the obstacles that were present in their life, one of which is the economic impact of the COVID-19 pandemic. The purpose of this research was to examine the quality of marriage of families who are economically affected during the pandemic. The method was a descriptive quantitative with the total number of 102 subjects who were recruited using convenience sampling. The main criteria used for selecting subjects was that they were married and economically affected due to the pandemic. Data were analyzed using cross-tabulation analysis. The result shows that people who are economically affected due to the COVID-19 pandemic has a moderate level of marital quality. The result of this study is expected to be used by the government as a basis for making programs to improve the quality of marriage among families who are economically affected during the COVID-19 pandemic.
\end{abstract}

Keywords: Marital quality, COVID-19 pandemic, economic impact

\begin{abstract}
Abstrak: Kualitas pernikahan merupakan sesuatu yang penting bagi setiap keluarga. Baik tidaknya kualitas pernikahan tentu saja bergantung dari bagaimana setiap pasangan bisa mengelola rintangan yang hadir dalam kehidupannya, salah satunya seperti dampak ekonomi selama pandemi COVID-19. Tujuan dari penelitian ini adalah untuk mengetahui gambaran kualitas pernikahan pada keluarga yang terdampak secara ekonomi selama pandemi. Metode penelitian ini adalah metode kuantitatif deskriptif dengan jumlah sampel 102 orang yang telah menikah dan terdampak secara ekonomi selama pandemi. Teknik pengambilan sampel pada penelitian ini menggunakan convenience sampling. Data dianalisis menggunakan cross-tabulation dengan bantuan program statistik. Dari hasil yang didapatkan, dapat disimpulkan bahwa kualitas pernikahan keluarga yang terdampak ekonomi selama pandemi memiliki tingkat kualitas sedang. Hasil penelitian ini diharapkan bisa digunakan oleh pemerintah sebagai dasar untuk membuat program dalam rangka untuk meningkatkan kualitas pernikahan pada keluarga yang terdampak ekonomi selama pandemi COVID-19.
\end{abstract}

Kata Kunci: Kualitas pernikahan, dampak ekonomi, pandemi COVID-19

World Health Organization (WHO) telah mengumumkan COVID-19 sebagai sebuah pandemi global (Arden \& Chilcot, 2020; Thomas-Rüddel et al., 2020). Menu- rut WHO, hingga 11 Mei 2021 setidaknya ada 158.651.638 kasus dengan angka kematian mencapai 3.299.764 di seluruh dunia (World Health Organization, 2021). Pande-

Korespondensi tentang artikel ini dapat dialamatkan kepada Kholifah Umi Sholihah melalui email: kholifahumisholihah@students.undip.ac.id 
mi COVID-19 juga dilaporkan telah mengakibatkan krisis kesehatan dan ekonomi yang luas, dengan tingkat kematian yang terus meningkat dan ancaman kehilangan pekerjaan (Hite \& McDonald, 2020).

Pandemi COVID-19 membawa perubahan besar bagi masyarakat dunia. Hal ini terjadi karena berbagai kebijakan yang ditetapkan pemerintah untuk melakukan pembatasan sosial. Khususnya di Indonesia kebijakan ini dikenal dengan Pembatasan Sosial Skala Besar (PSBB) yang menjadi salah satu langkah pencegahan penyebaran virus (Hasrul dalam Susanna, 2020). Kebijakan ini memaksa masyarakat untuk melakukan seluruh aktivitas, mulai dari bekerja, beribadah, hingga belajar dari rumah. Kebijakan pembatasan sosial atau lockdown bagi beberapa wilayah tersebut tentu saja membawa berbagai konsekuensi sosiologis dan psikologis yang mengakibatkan munculnya masalah dalam kehidupan sehari-hari dan ketidakstabilan keuangan (Gangopadhyaya \& Garrett, 2020).

Selama pandemi COVID-19, muncul berbagai permasalahan sehari-hari yang dapat berdampak salah satunya pada pernikahan. Kualitas pernikahan bisa bermasalah selama pandemi karena dipengaruhi salah satunya oleh faktor ekonomi (Tirajoh et al., 2021). Hal tersebut terjadi karena munculnya berbagai kebijakan yang memaksa masyarakat berada di rumah selama hampir 24 jam sehari dan adanya berbagai perubahan terkait aturan kerja. Dalam mewujudkan kehidupan pernikahan yang berkualitas, maka diperlukan peran keluarga yang harmonis, komunikasi yang lancar, dan keadaan ekonomi yang cukup (Puspitawati et al., 2019). Kualitas pernikahan yang dirasakan pasangan suami-istri juga dapat diukur melalui keadaan fisik yang baik dan hubungan yang harmonis (Bulunda et al., 2016). Kualitas pernikahan dapat dilihat dari adanya kepuasan pernikahan antar pasangan yang menjalankan siklus hidup berkeluarga (Puspitawati et al., 2019).

Gender, tingkat pendidikan, lama pernikahan, pilihan pasangan, pendapatan per- kapita, pembagian peran, kepuasan pernikahan dan ketahanan dalam pernikahan merupakan faktor-faktor yang dapat mempengaruhi kualitas pernikahan (Bradley \& Hojjat, 2017; Tyas et al., 2017). Pendapat lain menyebutkan bahwa tekanan ekonomi memiliki kaitan yang erat dengan kualitas pernikahan (Tyas \& Herawati, 2017). Sebuah keluarga akan memperoleh kebahagiaan salah satunya bersumber dari kondisi ekonomi yang mencukupi sehingga dapat memenuhi kebutuhannya. Kelas sosial atau status sosial ekonomi sebuah keluarga diketahui memiliki kaitan dengan kepuasan dan stabilitas dalam pernikahan (Conger et al., 2010). Kerenggangan hubungan dalam keluarga dapat disebabkan oleh permasalahan ekonomi. Tyas dan Herawati, (2017) melaporkan bahwa kerenggangan dan stres dalam keluarga terjadi karena faktor tingkat pendidikan dan pendapatan yang rendah

Munculnya stres disebabkan oleh kondisi ekonomi dalam keluarga telah lama dikaitkan dengan efek negatif pada kualitas pernikahan. Dinamika khusus dari pandemi COVID-19 adalah hilangnya pekerjaan secara tiba-tiba dan menjadi hal luar biasa yang dirasakan oleh masyarakat (Stanley \& Markman, 2020). Hal ini tidak terlepas dari munculnya kebijakan menjaga jarak dan lockdown yang ditetapkan di beberapa negara. Kebijakan lockdown misalnya telah memaksa perusahaan untuk melakukan perubahan pola kerja. Salah satu perubahannya adalah dengan penerapan kebijakan bekerja dari rumah (work from home) yang membutuhkan akses internet berkecepatan tinggi untuk kelangsungan bisnis (Velu et al., 2020). Namun dilaporkan juga bahwa banyak perusahaan yang terpaksa menutup aktivitas operasionalnya, sehingga mendorong perusahaan melakukan pemutusan hubungan kerja (PHK) terhadap para pekerja (Fahri et al., 2020).

Lebih lanjut dijelaskan bahwa dampak ekonomi lain yang dirasakan oleh pekerja akibat pandemi COVID-19 adalah adanya pemotongan gaji (Slavcheva, 2020). Bagi pekerja biasa yang terdampak secara eko- 
nomi, mereka akan memanfaatkan uang tabungan yang tidak cukup dapat menjamin keberlangsungan hidup sehingga dikhawatirkan akan memicu munculnya perilaku negatif (Slavcheva, 2020). Laporan dari Komisi Nasional Anti-Kekerasan terhadap Perempuan juga menyebutkan bahwa pandemi COVID-19 juga berefek pada kondisi ekonomi masyarakat. Faktor ekonomi ini menjadi salah satu yang menyebabkan suami-istri terpicu untuk bertengkar, dan bahkan dapat berdampak pada terjadinya kekerasan terhadap anak maupun pasangan. Faktor ekonomi yang dimaksud adalah berkurangnya penghasilan yang didapatkan, atau bahkan pasangan menjadi sama sekali tidak memiliki penghasilan sehingga gagal dalam memenuhi kebutuhan keluarganya (Merdeka.com, 2020).

Selain itu, adanya perubahan keadaan ekonomi keluarga selama pandemi juga membuat meningkatnya kasus perceraian. Perceraian di Indonesia pada bulan April dan Mei 2020 memcapai 20 ribu kasus dan kemudian pada bulan Juni dan Juli angka perceraian meningkat mencapai 57 ribu kasus (Detiknews, 2020). Kasus perceraian umumnya terjadi di pulau Jawa yang dilatarbelakangi oleh faktor ekonomi selama pandemi COVID-19 (Kurniawan et al., 2021). Kasus perceraian itu juga meningkat di Kota Batam. Pengadilan agama di Kota Batam mencatat peningkatan kasus mencapai 1.509 kasus. Kasus tersebut meningkat dari jumlah kasus yang ada pada tahun 2019. Pengadilan agama Batam menjelaskan bahwa munculnya perceraian dipicu oleh berbagai permasalahan, khususnya masalah ekonomi selama pandemi COVID19 (Maulana, 2020). Kasus perceraian itu juga terjadi di beberapa daerah lainnya seperti di provinsi Jawa Barat (Ranawati, 2020), kota Madiun (Liputan6, 2020), dan kota Surabaya (Kompas, 2020).

Berdasarkan latar belakang yang telah dijelaskan dapat dilihat bahwa dampak luar biasa terjadi saat pandemi COVID-19 dan dampak tersebut mempengaruhi kehidupan individu serta keluarga. Keadaan ekonomi menjadi salah satu faktor yang memicu munculnya permasalahan keluarga yang berakibat pada kualitas pernikahan individu menjadi menurun. Oleh sebab itu, studi ini bertujuan untuk meneliti kondisi kualitas pernikahan pada keluarga yang terdampak ekonomi selama pandemi COVID-19.

Penelitian terkait kualitas pernikahan selama pandemi sudah pernah dilakukan, misalnya tentang kepuasan pernikahan pada pasangan di Amerika Serikat (Williamson, 2020), kepuasan pernikahan pada keluarga di Iran (Mousavi, 2020) dan kualitas hubungan selama pandemi di Austria (Pieh et al., 2020). Dari beberapa penelitian yang pernah dilakukan, belum ada yang secara khusus membahas kualitas pernikahan pada individu yang terdampak secara ekonomi selama pandemi COVID-19, terutama di Jawa, sehingga penelitian ini perlu untuk dilakukan.

\section{Metode}

\section{Sampel}

Penelitian ini melibatkan 102 subjek yang terdiri dari 7 orang laki-laki dan 95 orang perempuan. Para subjek direkrut menggunakan convenient sampling seiring dengan penyebaran kuesioner secara online menggunakan google form. Setiap orang yang menerima link yang disebar melalui jaringan media sosial dan sesuai dengan kriteria subjek penelitian ini berkesempatan untuk berpartisipasi. Kriteria insklusi subjek adalah individu yang telah menikah dan mengalami dampak ekonomi selama pandemi COVID-19. Selain disebarkan secara online, kuesioner juga didistribusikan secara offline dengan memanfaatkan jaringan hubungan yang dimiliki oleh peneliti.

Subjek penelitian ini rata-rata berusia 38,13 tahun dengan SD usia adalah 9,68. Mayoritas subjek memiliki tingkat kelas ekonomi menengah ke bawah. Subjek berasal dari beberapa daerah di Jawa Tengah, yaitu Rembang, Semarang, Karanganyar, Banyumas, Kendal, Sragen, Banjarnegara, 
Grobogan, dan Tegal.

\section{Pengumpulan Data}

Skala yang digunakan untuk mengukur kualitas pernikahan adalah skala pengembangan dari indikator-indikator yang dibuat oleh Nurhayati (2015) yang dipilih dengan alasan sejumlah indikator tersebut sesuai dengan karakteristik subjek penelitian ini, yaitu sama-sama berasal dari latar belakang budaya Jawa. Skala yang digunakan untuk mengukur kualitas pernikahan merupakan skala jenis likert. Skala terdiri dari 41 item yang dalam proses pembuatan item melibatkan expert judgement yang memiliki latar belakang psikologi. Expert judgement diminta untuk menilai kesesuaian item berdasarkan indikator yang ada dan menilai makna serta kualitas item agar mudah dipahami oleh subjek penelitian. Reliabilitas skala pada penelitian ini adalah sebesar 9,68 , yang berarti memiliki reliabilitas yang tinggi.

\section{Analisis Data}

Penelitian ini merupakan penelitian kuantitatif deskriptif. Statistik deskriptif merangkum data pada variabel tunggal, seperti: rata-rata, median, mode, standar deviasi. Hasil dari data penelitian ini kemudian di analisis menggunakan crosstabulation. Analisis penelitian ini dipilih karena sesuai dengan tujuan dari penelitian, yaitu ingin mengetahui gambaran kualitas pernikahan keluarga selama pandemi COVID-19.

\section{Hasil}

Berdasarkan uji statistik deskriptif pada Tabel 1, didapatkan mean 158,95 dan SD 19,105. Dari mean dan SD yang didapatkan digunakan untuk membuat penggolongan kriteria tingkat kualitas pernikahan individu. Dari 102 subjek penelitian skor minimum yang didapatkan 82 dan skor maksimum sebesar 202. Kualitas pernikahan individu digolongkan ke dalam tiga kategori, yaitu rendah, sedang dan tinggi.

Berdasarkan Tabel 2, dapat dilihat bahwa terdapat 41 orang $(40,2 \%)$ memiliki kualitas pernikahan rendah, 47 orang $(46,1 \%)$ memiliki kualitas pernikahan sedang, dan 14 orang $(13,7 \%)$ memiliki kualitas pernikahan rendah. Berdasarkan kategorisasi tersebut dapat dilihat bahwa mayoritas subjek memiliki kualitas pernikahan sedang.

Berdasarkan Tabel 3, dapat dilihat bahwa ditinjau dari usia pernikahan, individu yang memiliki usia pernikahan 5-138 bulan memiliki rata-rata kualitas pernikahan pada tingkat sedang dengan persentase $40,7 \%$. Selain itu pada usia pernikahan yang sama terdapat $37 \%$ individu yang memiliki kualitas pernikahan yang rendah dengan jumlah 10 orang. Kemudian 22,2\% lainnya atau 6

Tabel 1. Statistik Deskriptif

\begin{tabular}{lccccc}
\hline & N & Minimum & Maximum & Mean & Std. Deviation \\
\hline Total & 102 & 82 & 202 & 158.95 & 19.105 \\
Valid N (listwise) & 102 & & & & \\
\hline
\end{tabular}

Tabel 2. Kategori kualitas Pernikahan

\begin{tabular}{clcccc}
\hline & & Frequency & Percent & Valid Percent & Cumulative (\%) \\
\hline \multirow{6}{*}{ Valid } & Rendah & 41 & 40.2 & 40.2 & 40.2 \\
& Sedang & 47 & 46.1 & 46.1 & 86.3 \\
& Tinggi & 14 & 13.7 & 13.7 & 100.0 \\
& Total & 102 & 100.0 & 100.0 & \\
\hline
\end{tabular}


orang memiliki kualitas pernikahan yang tinggi. Pada usia pernikahan 139-272 bulan, mayoritas individu atau sejumlah 25 orang memiliki kualitas pernikahan dengan kategori sedang $(49,0 \%)$. Kemudian terdapat 20 individu dengan persentase $39,2 \%$ yang memiliki kategori kualitas pernikahan rendah dan $11,8 \%$ lainnya atau 6 orang memi- liki kualitas pernikahan yang tinggi. Selanjutnya, pada usia pernikahan 273-406 bulan, mayoritas individu atau sebanyak 9 orang memiliki kualitas pernikahan level sedang $(56,2 \%)$, dan $37,5 \%$ lainnya atau 6 orang memiliki kualitas pernikahan pada kategori rendah dan $6,2 \%$ atau 1 orang memiliki kualitas pernikahan pada kategori

Tabel 3. Kualitas Pernikahan Ditinjau Dari Lama Usia Pernikahan

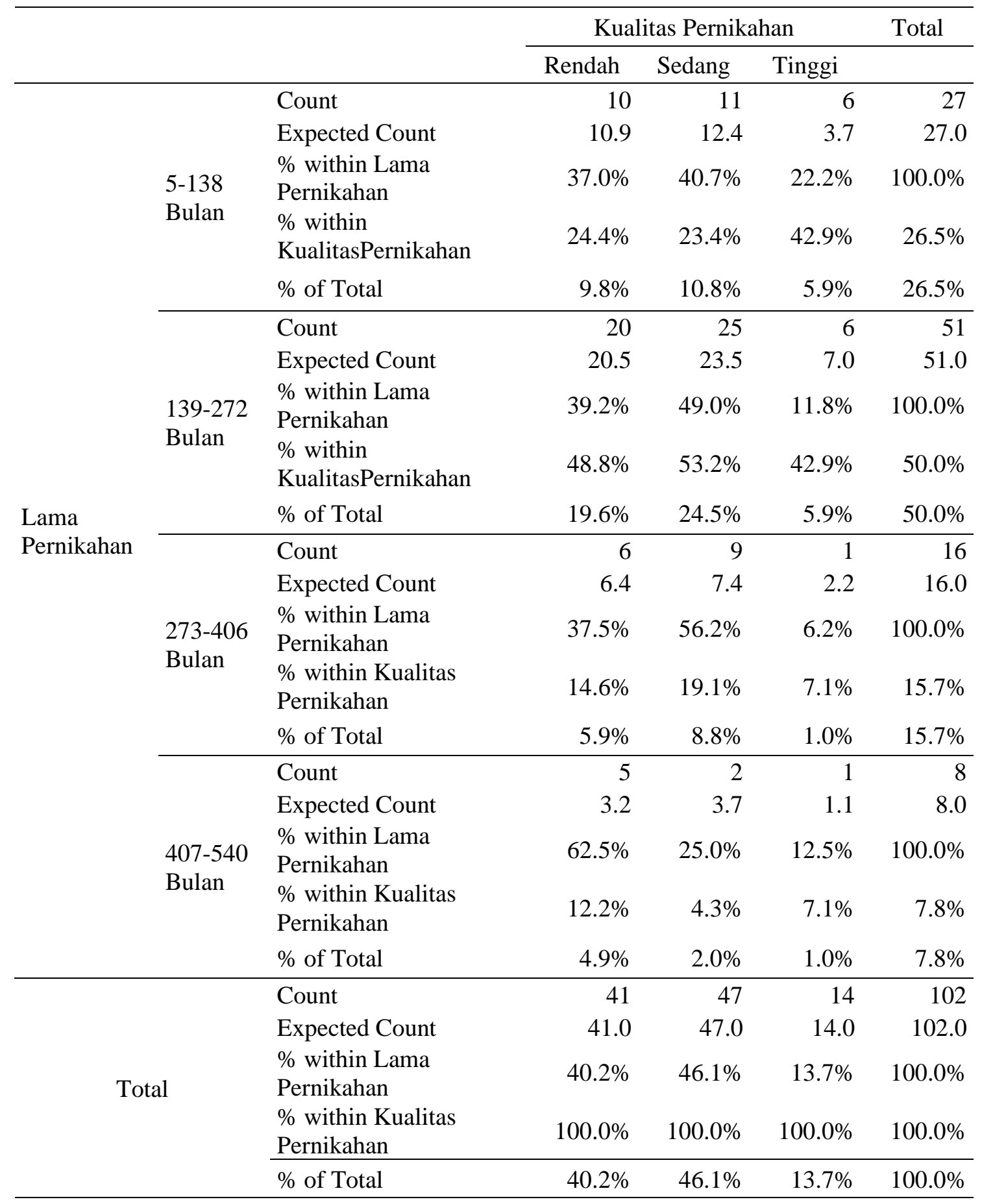


Tabel 4. Kualitas Pernikahan Ditinjau Dari Jenis Kelamin

\begin{tabular}{|c|c|c|c|c|c|c|}
\hline & & & \multicolumn{3}{|c|}{ Kualitas Pernikahan } & \multirow{2}{*}{ Total } \\
\hline & & & Rendah & Sedang & Tinggi & \\
\hline \multirow{10}{*}{$\begin{array}{l}\text { Jenis } \\
\text { Kelamin }\end{array}$} & \multirow{5}{*}{ Perempuan } & Count & 40 & 43 & 12 & 95 \\
\hline & & Expected Count & 38.2 & 43.8 & 13.0 & 95.0 \\
\hline & & $\%$ within Jenis Kelamin & $42.1 \%$ & $45.3 \%$ & $12.6 \%$ & $100.0 \%$ \\
\hline & & $\begin{array}{l}\text { \% within Kualitas } \\
\text { Pernikahan }\end{array}$ & $97.6 \%$ & $91.5 \%$ & $85.7 \%$ & $93.1 \%$ \\
\hline & & $\%$ of Total & $39.2 \%$ & $42.2 \%$ & $11.8 \%$ & $93.1 \%$ \\
\hline & \multirow{5}{*}{ Laki-laki } & Count & 1 & 4 & 2 & 7 \\
\hline & & Expected Count & 2.8 & 3.2 & 1.0 & 7.0 \\
\hline & & $\%$ within Jenis Kelamin & $14.3 \%$ & $57.1 \%$ & $28.6 \%$ & $100.0 \%$ \\
\hline & & $\begin{array}{l}\% \text { within Kualitas } \\
\text { Pernikahan }\end{array}$ & $2.4 \%$ & $8.5 \%$ & $14.3 \%$ & $6.9 \%$ \\
\hline & & $\%$ of Total & $1.0 \%$ & $3.9 \%$ & $2.0 \%$ & $6.9 \%$ \\
\hline \multirow{5}{*}{ Total } & & Count & 41 & 47 & 14 & 102 \\
\hline & & Expected Count & 41.0 & 47.0 & 14.0 & 102.0 \\
\hline & & $\%$ within Jenis Kelamin & $40.2 \%$ & $46.1 \%$ & $13.7 \%$ & $100.0 \%$ \\
\hline & & $\begin{array}{l}\% \text { within Kualitas } \\
\text { Pernikahan }\end{array}$ & $100.0 \%$ & $100.0 \%$ & $100.0 \%$ & $100.0 \%$ \\
\hline & & $\%$ of Total & $40.2 \%$ & $46.1 \%$ & $13.7 \%$ & $100.0 \%$ \\
\hline
\end{tabular}

tinggi. Pada usia pernikahan 407-540 bulan, mayoritas subjek memiliki kualitas pernikahan yang rendah dengan persentase sebesar $62,5 \%$ atau sebanyak 5 orang. Lalu, terdapat $25 \%$ atau sejumlah 2 subjek memiliki kategori sedang dan 7,1\% lainnya memiliki kategori kualitas pernikahan tinggi pada usia pernikahan paling lama dari semua subjek penelitian ini.

Berdasarkan Tabel 4, dapat dilihat data kualitas pernikahan ditinjau dari jenis kelamin. Jumlah subjek perempuan sebanyak 95 orang dan laki-laki sebanyak 7 orang. Kualitas pernikahan pada mayoritas perempuan sebanyak 43 orang berada dalam kategori sedang $(45,3 \%)$. Kemudian, terdapat $38,2 \%$ atau 40 perempuan memiliki kualitas pernikahan rendah dan $13 \%$ atau sebanyak 12 orang berada pada kategori tinggi. Data lainnya menunjukkan kualitas pernikahan pada subjek laki-laki mayoritas berada pada kategori sedang dengan presentasi $57,1 \%$ atau sebanyak 4 orang dari total jumlah lakilaki. Lalu, terdapat $14,3 \%$ atau 1 orang lakilaki yang berada pada kategori rendah dan
$28,6 \%$ atau 2 orang berada pada kategori kualitas pernikahan tinggi.

\section{Pembahasan}

Hasil penelitian ini menunjukkan bahwa kualitas pernikahan pada para subjek yang terdampak secara ekonomi selama pandemi pada umumnya tergolong pada kategori sedang. Kategori sedang pada kualitas pernikahan ini mengindikasikan hubungan pernikahan pada para subjek tergolong tidak cukup baik. Hal Tersebut selaras dengan pendapat Yalber (dalam Indiana University, 2020) yang menjelaskan bahwa pandemi COVID-19 menyebabkan munculnya peningkatan stres, kekhawatiran terhadap pekerjaan rumah dan pengasuhan anak bagi beberapa orang yang sudah menikah, yang dapat mengakibatkan ketegangan pada perkawinan.

Kevin dan Risla (dalam Mousavi, 2020) juga menjelaskan bahwa individu yang memiliki penghasilan yang rendah maka akan memiliki kepuasan pernikahan 
yang rendah selama pandemi. Rendahnya kondisi kualitas hubungan individu selama pandemi ini menjadi sebuah faktor resiko bagi putusnya hubungan antara pasangan (Pieh et al., 2020).

Hasil penelitian ini, yang menunjukkan bahwa kualitas pernikahan pada para subjek yang berasal dari Jawa Tengah selama pandemi berada dalam kategori sedang, berbeda dengan penelitian sebelumnya. Hasil penelitian Setiawati dan Nurhayati (2020) menunjukkan para subjeknya yang berasal dari etnis Jawa memiliki kualitas tinggi. Adanya perbedaan tersebut dimungkinkan terjadi karena perbedaan karakteristik subjek dan konteks penelitian. Setiawati dan Nurhayati (2020) meneliti subjek pada konteks umum, sementara pada penelitian ini karakteristik subjeknya adalah orang yang terdampak secara ekonomi selama pandemi COVID-19. Williamson (2020) menjelaskan bahwa apabila pasangan memiliki fungsi yang rendah maka kepuasan hubungan antar pasangan pun akan menurun. Fungsi tersebut salah satunya adalah dalam pemenuhan kebutuhan ekonomi. Saidiyah dan Julianto (2017) juga melaporkan bahwa faktor ekonomi seringkali menjadi masalah utama yang dihadapi oleh pasangan. Hal ini terjadi karena permasalahan ekonomi juga memiliki pengaruh secara negatif terhadap kesejahteraan diri individu (Raharjo et al., 2015). Adanya dampak pada kesejahteraan itu, tentu saja bisa jadi berdampak pada kualitas pernikahannya.

Kemudian, ditinjau dari lama usia pernikahan, didapatkan hasil bahwa kualitas pernikahan mayoritas berada pada kategori sedang, akan tetapi pada usia pernikahan 407-540 bulan atau usia terlama dari usia pernikahan subjek, mayoritas memiliki kualitas pernikahan yang rendah. Hal ini berbeda dengan temuan Allendorf dan Ghimire (2013) yang menyatakan bahwa semakin lama usia pernikahan seseorang maka semakin bagus kualitas pernikahannya. Alasannya adalah karena pasangan akan lebih bisa menyelesaikan berbagai masalah keluarga. Namun, kemampuan dalam menye- lesaikan masalah keluarga pada pasangan tidak semata ditentukan oleh usia pernikahan. Rendahnya kualitas pernikahan pada pasangan yang memiliki usia pernikahan terlama pada penelitian ini, yaitu 407-540 bulan atau sekitar 33,9-45 tahun bisa jadi dipengaruhi oleh banyak faktor. Matondang (2014) menyebutkan bahwa semakain lama pasangan itu menikah maka kewajiban yang harus dijalankan oleh pasangan akan semakin banyak, terlebih lagi apabila ketika telah memiliki anak. Selain itu, dampak munculnya perubahan ekonomi yang mendadak selama pandemi juga bisa menjadi faktor lainnya. Afni dan Indrijati (2011) menjelaskan bahwa faktor ekonomi dapat menyebabkan perceraian antara pasangan yang telah menikah.

Selain itu, penelitian ini menununjukkan bahwa subjek pada usia pernikahan lebih awal memiliki kategori sedang dalam kualitas pernikahannya. Wardhani (2012) menjelaskan bahwa pada usia awal pernikahan, komunikasi antar pasangan menjadi faktor penentu kepuasan pernikahan. Penelitian Rumondor (2011) melaporkan bahwa, pada usia awal pernikahan, individu merasa puas dengan pernikahannya, suka untuk mengekspresikan kasih sayang melalui kontak fisik meskipun terkadang sesekali masih berselisih paham tentang sesuatu. Faktor lain yang dapat menjelaskan kategori sedang dalam usia pernikahan awal pada subjek penelitian ini adalah penyesuaian dalam pernikahan. Rahmah et al (2018) melaporkan hasil penelitian yang menyimpulkan bahwa penyesuaian dalam pernikahan terbukti berpengaruh terhadap kualitas pernikahan.

Kemudian ditinjau dari jenis kelamin, penelitian ini mendapatkan hasil bahwa tidak ada perbedaan kualitas pernikahan pada laki-laki dan perempuan. Laki-laki dan perempuan sama-sama memiliki kualitas pernikahan kategori sedang. Temuan ini berbeda dengan penelitian Mousavi (2020) yang melaporkan bahwa laki-laki di Iran memiliki kepuasan pernikahan yang lebih tinggi dari pada perempuan. Namun, 
temuan penelitian ini selaras dengan hasil penelitian terdahulu di Indonesia. Setiawati dan Nurhayati (2020) melaporkan bahwa jenis kelamin tidak terbukti menjadi faktor penentu kualitas pernikahan pasangan. Penelitian Kendhawati dan Purba (2019) juga menyimpulkan bahwa faktor demografi seperti jenis kelamin tidak mempengaruhi kualitas pernikahan seseorang.

\section{Simpulan}

Penelitian ini menemukan bahwa kualitas pernikahan individu yang terdampak ekonomi selama pandemi COVID-19 berada pada ketegori sedang. Ditinjau dari lamanya usia pernikahan, mayoritas individu yang memiliki usia pernikahan 407-540 bulan atau 33,9-45 tahun memiliki kategori kualitas pernikahan yang rendah. Ditinjau dari perbedaan gender, antara perempuan dan laki-laki memiliki persamaan kualitas pernikahan yaitu sama-sama berada pada kategori sedang.

\section{Saran}

Hasil penelitian ini bisa digunakan sebagai dasar perlunya program-program yang bertujuan untuk mengatasi masalah pernikahan selama masa pandemi COVID19 terutama pada keluarga yang terdampak secara ekonomi. Bagi peneliti selanjutnya, disarankan untuk menguji kualitas pernikahan pada masa pandemi dengan variabel lainnya untuk mengetahui prediktor kualitas pernikahan khususnya pada mereka yang terdampak secara ekonomi akibat pandemi COVID-19.

\section{Daftar Pustaka}

Afni, N., \& Indrijati, H. (2011). Pemenuhan aspek-aspek kepuasan perkawinan pada istri yang menggugat cerai. Jurnal Insan, 13(03), 176-184. http://www.journal.unair.ac.id/filerP DF/5-13_3.pdf

Allendorf, K., \& Ghimire, D. J. (2013). Determinants of marital quality in an arranged marriage society. Social Science Research, 42(1), 59-70. https://doi.org/10.1016/j.ssresearch.2 012.09 .002

Arden, M. A., \& Chilcot, J. (2020). Health psychology and the coronavirus (COVID-19) global pandemic: A call for research. British Journal of Health Psychology, 25(2), 231-232. https://doi.org/10.1111/bjhp.12414

Bradley, J. M., \& Hojjat, M. (2017). A model of resilience and marital satisfaction. J Soc Psychol, 157(5), 588-601. https://doi.org/10.1080/002245445.2 016.1254592
Bulunda, J. R., Brown, J. S., \& Yamashita, T. (2016). Marital quality, marital dissolution, and mortality risk during the later life course. Social Science and Medicine, 165, 119-127. https://doi.org/10.1016/j.socscimed.2 016.07.025

Conger, R. D., Conger, K. J., \& Martin, M. J. (2010). Socioeconomic status, family processes, and indivisual development. Journal of Marriage and Family, 72, 685-704. https://doi.org/10.1111/j.17413737.2010.00725.x

Detiknews. (2020, Agustus $28^{\text {th }}$ ). Perceraian di pulau jawa meningkat gegara pandemi COVID-19. https://news.detik.com/berita/d5150980/perceraian-di-pulau-jawameningkat-gegara-pandemi-covid-19

Fahri, Jalil, A., \& Kasnelly, S. (2020). Meningkatnya angka pengangguran ditengah pandemi (COVID-19). Al Mizan:Jurnal Ekonomi Syariah, 2(2), 
45-60.

www.ejournal.annadwahkualatungka 1.ac.id

Gangopadhyaya, A., \& Garrett, B. (2020). Unemployment, health insurance, and the COVID-19 recession. SSRN, 1-8. https://www.urban.org/sites/default/fi les/publication/101946/unemployme nt-health-insurance-and-the-covid19-recession_1.pdf

Hite, L. M., \& McDonald, K. S. (2020). Careers after COVID-19: challenges and changes. Human Resource Development International, 23(4), 427-437.

https://doi.org/10.1080/13678868.20 20.1779576

Indiana University. (2020). COVID-19 Impact on marital quality. https://research.impact.iu.edu/ourstrengths/coronavirus/marriagequality.html

Kendhawati, L., \& Purba, F. D. (2019). Hubungan kualitas pernikahan dengan kebahagiaan dan kepuasan hidup pribadi: Studi pada individu dengan usia pernikahan 1-5 tahun di Bandung. Jurnal Psikologi, 18(1), 106.

https://doi.org/10.14710/jp.18.1.106115

Kompas. (2020, September $10^{\text {th }}$ ). Kasus perceraian meningkat di surabaya selama pandemi COVID-19. https://www.kompas.tv/article/10754 0/kasus-perceraian-meningkat-disurabaya-selama-pandemi-covid-19

Kurniawan, I. G. H., Judge, Z., Olivia, F., Suprayogi, A., Redjeki, S., Siswanto, A. H., \& Arianto, H. (2021). Pengaruh pandemi COVID-19 terhadap maraknya kasus perceraian di berbagai pengadilan agama. Jurnal Abdimas, 7(2), 95-99. https://ejurnal.esaunggul.ac.id/index. php/ABD/article/viewFile/3954/2949
Liputan6. (2020, September $24^{\text {th }}$ ). Ada 989 kasus perceraian di madiun selama pandemi COVID-19. Liputan6.Com. https://surabaya.liputan6.com/read/4 365298/ada-989-kasus-perceraian-dimadiun-selama-pandemi-covid-19

Matondang, A. (2014). Faktor-faktor yang mengakibatkan perceraian dalam perkawinan. Jurnal Ilmu Pemerintahan dan Sosial Politik, 2(2), 141-150.

http://ojs.uma.ac.id/index.php/jppum a

Maulana, H. (2020, September 17). Selama pandemi, gugatan cerai di batam mencapai 1.509 kasus. https://regional.kompas.com/read/20 20/09/17/15515981/selama-pandemigugatan-cerai-di-batam-mencapai1509-kasus

Merdeka.com. (2020, Agustus $25^{\text {th }}$ ). Penyebab angka perceraian meningkat selama pandemi COVID19.

https://www.merdeka.com/peristiwa/ penyebab-angka-perceraianmeningkat-selama-pandemi-covid19.html?page $=1$

Mousavi, S. F. (2020). Psychological wellbeing, marital satisfaction, and parental burnout in iranian parents: The effect of home quarantine during COVID-19 outbreaks. Frontiers in Psychology, 11:553880. https://doi.org/10.3389/fpsyg.2020.5 53880

Nurhayati, S. R. (2015). Konsep, dimensi, dan pengukuran kualitas perkawinan (Disertasi). Universitas Negeri Yogyakarta. https://eprints.uny.ac.id/36013/1/lapo ran akhir .pdf

Pieh, C., O'Rourke, T., Budimir, S., \& Probst, T. (2020). Relationship quality and mental health during COVID-19 lockdown. PLOS ONE, 
15(9), 1-10.

https://doi.org/10.1371/journal.pone. 0238906

Puspitawati, H., Azizah, Y., Mulyana, A., \& Rahmah, A. . (2019). Relasi gender, ketahanan keluarga dan kualitas pernikahan pada keluarga nelayan dan buruh tani "Brondol" bawang merah. Jurnal Ilmu Keluarga Dan Konsumen, 12(1), 1-12. https://doi.org/10.24156/jikk.2019.12 .1 .1

Raharjo, I. T., Puspitawati, H., \& Krisnatuti, D. (2015). Tekanan ekonomi, manajemen keuangan dan kesejahteraan pada keluarga muda. Ilmu Keluarga Dan Konsumen, 8(1), 38-48.

https://journal.ipb.ac.id/index.php/jik k/article/view/10017/7835

Rahmah, A. A., Rahman, A. A., \& Anisah, F. E. (2018). Prediktor kualitas pernikahan: penyesuaian pernikahan dan nilai personal (Dissertation). UIN Sunan Gunung Djati, Bandung. http://digilib.uinsgd.ac.id/4835/

Ranawati, N. K. (2020, September $8^{\text {th }}$ ). Perceraian di Jabar tinggi selama pandemi, komunikasi jadi sorotan. https://ayobandung.com/read/2020/0 9/08/127042/perceraian-di-jabartinggi-selama-pandemi-komunikasijadi-sorotan

Rumondor, P. C. B. (2011). Gambaran penyesuaian diadik pada pasangan dewasa muda di awal pernikahan. Humaniora, 2(1), 468. https://doi.org/10.21512/humaniora.v $2 \mathrm{i} 1.3057$

Saidiyah, S., \& Julianto, V. (2017). Problem pernikahan dan strategi penyelesaiannya: Studi kasus pada pasangan suami istri dengan usia perkawinan di bawah sepuluh tahun. Jurnal Psikologi, 15(2), 124-133. https://doi.org/10.14710/jpu.15.2.124
$-133$

Setiawati, F. A., \& Nurhayati, S. R. (2020). Kualitas perkawinan orang Jawa: Tinjauan faktor jenis kelamin, usia perkawinan, jumlah anak, dan pengeluaran keluarga. Jurnal Ilmu Keluarga Dan Konsumen, 13(1), 1324.

http://jurnal.ipb.ac.id/index.php/jikk/ article/view/27857/19216

Slavcheva, I. (2020). Working or workless poor: The effect of pandemics. Economic, 129-137. https://uevarna.bg/ uevarna/uploads/filemana ger/303/publishingcomplex/2020/Economic_science_ed ucation_real_economy_T4_2020.pdf

Stanley, S. M., \& Markman, H. J. (2020). Helping couples in the shadow of COVID-19. Family Process, 59(3), 937-955. https://doi.org/doi: 10.1111/famp. 12575

Susanna, D. (2020). When will the COVID19 pandemic in indonesia end? Kesehatan Masyarakat, 15(4), 160162.

https://doi.org/10.21109/KESMAS.V $15 \mathrm{I} 4.4361$

Thomas-Rüddel, D., Winning, J., Dickmann, P., Ouart, D., Kortgen, A., Janssens, U., \& Bauer, M. (2020). Coronavirus disease 2019 (COVID19): Update for anesthesiologists and intensivists March 2020. Der Anaesthesist.

https://doi.org/10.1007/s00101-02000760-3

Tirajoh, C. V, Munayang, H., \& Kairupan, B. H. R. (2021). Dampak pembelajaran jarak jauh terhadap kecemasan orang tua murid di masa pandemi COVID-19. Jurnal Biomedik, 13(1), 49-57. https://doi.org/10.35790/jbm.13.1.20 21.31715 
Tyas, F. P. S., \& Herawati, T. (2017). Kualitas pernikahan dan kesejahteraan keluarga menentukan kualitas lingkungan pengasuhan anak pada pasangan yang menikah usia muda. Jurnal Ilmu Keluarga Dan Konsumen, 10(1), 1-12. https://doi.org/10.24156/jikk.2017.10 .1 .1

Tyas, F. P. S., Herawati, T., \& Sunarti, E. (2017). Tugas perkembangan keluarga dan kepuasan penikahan pada pasangan menikah usia muda. Jurnal Ilmu Keluarga Dan Konsumen, 10(2), 83-94. https://doi.org/10.24156/jikk.2017.10 .2 .83

Velu, S. R., Gopinathan, S., \& Raman, M. (2020). Competency sssessment for or - COVID-19. In Journal of Humanities and Social Sciences Research, 2(S), 111-130). https://doi.org/10.37534/bp.jhssr.202 0.v2.ns.id1031.p111

Wardhani, N. A. K. (2012). Self disclosure dan kepuasan perkawinan pada istri di usia awal perkawinan. Calyptra: Jurnal Ilmiah Mahasiswa Universitas Surabaya, 1(1), 1-9. https://journal.ubaya.ac.id/index.php/ jimus/article/view/68

Williamson, H. C. (2020). Early effects of the COVID-19 pandemic on relationship satisfaction and attributions. Psychological Science, 31(12), 1479-1487. https://doi.org/10.1177/09567976209 72688

World Health Organization. (2021, Mei 11 th). WHO coronavirus (COVID-19) dashboard. Retrieved from https://covid19.who.int/ 